Original Research

\title{
Related Factors of a Nurse Handover Implementation in the Inpatient Ward of Ulin Hospital, Banjarmasin
}

\author{
Ahmad Juliadi' ${ }^{1}$, Bahrul Ilmi ${ }^{2}$ and Hiryadi Hiryadi ${ }^{1}$ \\ ${ }^{1}$ University of Muhammadiyah Banjarmasin, Indonesia \\ 2 Poltekes Kemenkes Banjarmasin Indonesia
}

\begin{abstract}
Introduction: Ideally, a handover is carried out through three stages: preparation, implementation, and post-handover. However, some handovers only consist of one phase. The aim of the study was to identify and analyze the factors related to the implementation of nurse handover.

Methods: This was a correlative analytic research method with a crosssectional approach. The population in this study was all of the nurses with at least a Diploma III inpatient ward education. The sample totaled 174 nurses in the inpatient ward of Ulin Hospital Banjarmasin, recruited through proportionate stratified random sampling. The data was collected by spreading the questionnaire and the data collection took place from December 2017 to January 2018.

Results: There was a correlation between education level $(p=0.036)$ and role model $(\mathrm{p}=0.021)$ with the implementation of handover. The most dominant factor associated with the implementation of handover was role model $(\mathrm{p}=0.031$ : $\mathrm{OR}=6.089)$.

Conclusion: The nurses who had a good role model performed th handover 6.089 times better than the nurses with an inadequate role model. Adversely, a poor role model might result in a poor handover.
\end{abstract}

\section{ARTICLE HISTORY}

Received: Dec 26, 2019

Accepted: Dec 31, 2019

\section{KEYWORDS}

education; nurse handover; role model

\section{CONTACT}

Ahmad Juliadi

$\triangle$ ahmad.juliadi@yahoo.co.id

$\equiv$ University of Muhammadiyah

Banjarmasin, Indonesia

Cite this as: Juliadi, A., Ilmi, B., \& Hiryadi, H. (2019). Related Factors of a Nurse Handover Implementation in the Inpatient Ward of Ulin Hospital, Banjarmasin. Jurnal Ners, 14(3si), 13-20. doi:http://dx.doi.org/10.20473/jn.v14i3(si).16949

\section{INTRODUCTION}

Targeting patient safety is a requirement to be applied in all hospitals accredited by the Hospital Accreditation Commission. The preparation of this target refers to the Nine Life-Saving Patient Safety Solutions from Organization and others (2007), which was also used by the PERSI Hospital Patient Safety Committee (KKPRS PERSI) and by the Joint Commission International (JCI) (Permenkes RI, 2011).

The importance of effective communication is certainly inseparable from the nurses or other health workers. Nurses, in this case, are very good at communicating when doing nursing care, one of which is the handover. In line with (Safitri, 2012), it was revealed that the main thing needed by each inpatient is nursing care. One of the nursing care methods provided is the handover procedure, which is a daily activity that must be carried out by the nurse. The handover implementation carried out by the nurses is a nursing action that will directly impact on patient care. Besides that, the patient handover is built as a means to convey responsibility and it is a submission of legality related to the nursing services and the patients.

Professionalism in the nursing services can be achieved by optimizing the role and functions of the nurses, especially when they are more independent. This can be realized well through effective communication, as well as with other health teams. One form of communication that needs to be improved is when changing shifts (weighing the patients) (Nursalam, 2015).

Alvarado et al (2006), in their (Triwibowo, Harahap, \& others, 2016) study, revealed that inaccurate information can have a serious impact on the patients. Almost $70 \%$ of sentinel events are those that result in death or serious injury in the hospitals due to poor communication. The statement of the 
researchers above is in line with the statement of Angood (2007). In the research of Dewi (2012), they revealed that there are adverse events, near miss and sentinel events in hospitals. The problem that is the main cause is poor communication.

The World Health Organization (WHO) (2007) reported that in $1995-2006,11 \%$ out of 25.000 to 30.000 cases of communication errors during the handover of patients caused permanent disabilities which actually prevented side effects.

The second nurse said that the patient's handover was done at the nurse's table and then with the patient with each team. The nurse returned to the nurse's table after the patient was finished, but when weighing in the patient's room, they only observed the patients who reported it. They delivered the information in more detail and with priority, while for the patients who were safe to just continue with the therapy, sometimes at the time of the handover being completed from the patient to the nurse's desk, the nurses who had served previously immediately went home and did not sit together again at the nurses' table with the nurses who served next. The third nurse said that the handover was indeed done at the nurse's desk. After the handover was finished at the nurse's desk, the night service went home. There was no patient interaction along with the morning service, even when the nurse said that he was only patient after the night service returned.

Based on the data above, it shows that the behavior of the nurses in applying the handovers has not been carried out maximally. This shows that the communication at the time of the shift exchange between the nurses and between the patients and nurses has not gone well. The handover should not only be done at the nurse station but rather, it should be carried out directly in the patient's room. This phenomenon is in line with the research of Triwibowo \& Harahap (2016) about qualitative studies.

Based on the results of the observations conducted by the researchers at the end of the morning service, it was found that the nurses serving on the next shift did not arrive earlier. This could also affect the handover and the handovers were not done on time. The time was limited so then the handovers were only done at the nursing station. It was observed that when the room nurse passed between the morning shift, the handover performed by the nurse was only done at the nurse's desk. The results of the observations were also supported by the interviews with the nurses who were in the afternoon service. When asked whether the handovers were also carried out by the patient, the nurse answered no. The results of the observations carried out above are inversely proportional to what was stated by (Nursalam, 2014) and (Nursalam, 2015), in that the handovers are carried out in three stages. The first stage of preparation was carried out at the nurse station. The second stage was the implementation carried out at the nurse station and also in the room or bed of the patient and the third stage was post-weighing what was carried out at the nurse station. From this description, it can be concluded that the handovers performed by the nurses were not carried out in full according to the set stages. The second stage was cut off at the patient's room or bed directly, which included the head of room delivering greetings and the primary nurse (PP) asking for the patient's basic needs. The nursing nurse will further examine the nursing problems, needs, and actions that have been or have not been implemented, in addition to other important things that need to be noted during the treatment period.

The nurses' knowledge in the application of the handover of the patients is useful for the nurses so then the nurses can play a role in patient safety. This is because the nurses have a large role in collaborative actions with their clients, families and other health workers in accordance with their responsibilities based on the weighing process carried out. The variables were weighed and received as being effective, timely, accurate, complete, with clear communication and the handover was able to be understood by the patients. This will reduce errors, and result in improved patient safety. For the nurses themselves to weigh it, it served as a support for their colleagues in carrying out the nursing care actions. This can reduce the anxiety that occurs in the nurses, as well as providing motivation, improving the communication skills between nurses and establishing a cooperative and responsible relationship between the nurses. The nurses can comprehensively follow patient development, the patients get optimal health care and they can convey any problems directly if there is something that has not been revealed. It also allows the hospital to be able to improve the nursing services to the patients comprehensively. Based on the description above, the researcher is interested in examining more deeply the factors associated with the implementation of nurse handover.

\section{MATERIALS AND METHODS}

This research was a correlative analytical research study conducted using a cross-sectional design. This study used a cross-sectional approach because this study intended to identify whether there was a relationship between the level of education, attitude, motivation, intention, workload, role model and a strict time limits on the nurses' handover as the implementation variables. This study analyzed the factors associated with the implementation of the nurse handover in the Inpatient Ward of Ulin Hospital Banjarmasin.

The sample in this study consisted of the implementing nurses in the inpatient ward of Ulin Hospital Banjarmasin. The sample size in this study totaled 174 people. The research was conducted from the beginning of the planning and proposals, namely in April 2017, and then the data collection was carried out from December 2017 to January 2018. 
Table 1. Distribution of the respondents according to education level, motivation, attitude, intention, role model, strict time constraints, workload and the handover implementation of nurses in the inpatient ward of Ulin Hospital Banjarmasin; 174 respondents.

\begin{tabular}{|c|c|c|c|}
\hline Variable & Category & $\mathbf{n}$ & $(\%)$ \\
\hline \multirow[t]{3}{*}{ Level of education } & $\begin{array}{l}\text { Professional Education (Ners and } \\
\text { Specialist Ners) }\end{array}$ & 29 & 16.7 \\
\hline & $\begin{array}{l}\text { Academic Education (Bachelor of Nursing } \\
\text { and Masters in Nursing) }\end{array}$ & 14 & 8.0 \\
\hline & $\begin{array}{l}\text { Vocational Education (Intermediate } \\
\text { nursing and applied science graduates) }\end{array}$ & 131 & 75.3 \\
\hline \multirow[t]{3}{*}{ Motivation } & High & 142 & 81.6 \\
\hline & Moderate & 32 & 18.4 \\
\hline & Low & 0 & 0 \\
\hline \multirow[t]{2}{*}{ Attitude } & Positive & 98 & 56.3 \\
\hline & Negative & 76 & 43.7 \\
\hline \multirow[t]{2}{*}{ Intention } & Strength & 166 & 95.4 \\
\hline & Weak & 8 & 4.6 \\
\hline \multirow[t]{2}{*}{ Role model } & Well & 167 & 96.0 \\
\hline & Not good & 7 & 4.0 \\
\hline \multirow[t]{2}{*}{ Strict time limits } & Right & 160 & 92.0 \\
\hline & Not exactly & 14 & 8.0 \\
\hline \multirow[t]{2}{*}{ Workload } & High & 67 & 38.5 \\
\hline & Low & 107 & 61.5 \\
\hline \multirow[t]{2}{*}{ Handover implementation } & Good & 157 & 90.2 \\
\hline & Poor & 17 & 9.8 \\
\hline
\end{tabular}

Table 2. Relationship between education level and the handover implementation of nurses in the inpatient ward of Ulin Hospital Banjarmasin.

\begin{tabular}{|c|c|c|c|c|c|c|}
\hline \multirow{3}{*}{ Level of education } & \multicolumn{4}{|c|}{ Handover implementation } & \multicolumn{2}{|c|}{ Total } \\
\hline & \multicolumn{2}{|c|}{ Well } & \multicolumn{2}{|c|}{ Not good } & \multirow[b]{2}{*}{$\mathbf{n}$} & \multirow[b]{2}{*}{$\%$} \\
\hline & $\mathbf{n}$ & $\%$ & $\mathbf{n}$ & $\%$ & & \\
\hline Professional Education \& Academic Education & 35 & 81.4 & 8 & 18.6 & 43 & 24.71 \\
\hline Vocational Education & 122 & 93.1 & 9 & 6.9 & 131 & 75.29 \\
\hline Total & 91 & 52.3 & 83 & 47.7 & 174 & 100 \\
\hline Fisher's exact test $p$ value 0.036 & \multicolumn{6}{|c|}{$\mathrm{OR}=0.323(0.116-0.898)$} \\
\hline
\end{tabular}

The variables were level of education, attitude, motivation, intention, workload, role model and strict time limits. The instrument in this study was a questionnaire.

The procedures in this study were where the researcher chose one nurse in each room who worked in the inpatient ward of Ulin Banjarmasin Hospital as an assistant in this study. The research assistant had the same role as the researcher. This role was carried out when the researcher was not in the hospital. They were to provide guidance and understanding to the research assistants about the procedures and how to fill out the questionnaires. The determination of the respondents was done by the means of researchers / research assistants according to the names registered as the research population. They provided an explanation of the objectives, benefits and research procedures carried out and presented to the respondents. We asked the respondent to fill in the consent sheet in order to become a respondent after agreeing to be a participant in the research conducted.

The data analysis in this study included univariate, bivariate and multivariate analysis. Univariate analysis aimed to describe the characteristics of each variable studied. The bivariate analysis used to test hypotheses with $\alpha 0.05$ was intended to test the relationship of each independent variable and dependent variable using a Chi-square test and Fisher's exact test. Multivariate analysis was performed to assess the variables that had the most influence on the implementation of nurse handovers. The multivariate analysis used was a multiple logistic regression test, because in this study it was used to analyze the relationship of one or several independent variables with a categorical variable. This is said to be regression logistics and the variable was used to get the best model that can describe the relationship between the independent and dependent variables.

The researcher noted that ethical clearance consists of the right to self-determination, the right to privacy and dignity, the right to anonymity and confidentiality, the right to fair treatment and the right to protection from discomfort and harm.

\section{RESULTS}

The respondents' distribution, level of education, motivation, attitude, intention, role model, strict time limits, workload and handover implementation have been examined. See on table 1 .

The results of the bivariate analysis found that motivation, attitude, intention, strict time limits and workload were not related to handover implementation. The level of education and role model were related to the 
Table 3. Relationship between role models and the implementation of handover in the inpatient ward of Ulin Hospital Banjarmasin

\begin{tabular}{|c|c|c|c|c|c|c|}
\hline \multirow{3}{*}{ Role model } & \multicolumn{4}{|c|}{ Handover implementation } & \multicolumn{2}{|c|}{ Total } \\
\hline & \multicolumn{2}{|c|}{ Well } & \multicolumn{2}{|c|}{ Not good } & \multirow[b]{2}{*}{$\mathbf{n}$} & \multirow[b]{2}{*}{$\%$} \\
\hline & $\mathbf{n}$ & $\%$ & $\mathbf{n}$ & $\%$ & & \\
\hline Well & 153 & 91.6 & 14 & 8.4 & 167 & 95.98 \\
\hline Not good & 4 & 57.1 & 3 & 42.9 & 7 & 4,02 \\
\hline Total & 157 & 90.2 & 17 & 9.8 & 174 & 100 \\
\hline Fisher's exact test $\mathrm{p}$ value 0.021 & \multicolumn{4}{|c|}{$\mathrm{OR}=8.196(1.665-40.384)$} & & \\
\hline
\end{tabular}

Table 4. The recapitulation of the relationship between the level of education, motivation, attitude, intention, role model, strict time constraints and workloads with the implementation of the handover in the inpatient ward of Ulin Hospital Banjarmasin

\begin{tabular}{lccc}
\hline Variable & P value & OR & 95\%CI \\
\hline Level of education & $0.094^{*}$ & 0.639 & $0.111-3.661$ \\
Motivation & $0.243^{*}$ & 2.006 & $0.653-6.165$ \\
Attitude & 0.768 & 1.163 & $0.427-3.173$ \\
Intention & 0.797 & 1.339 & $0.155-11.587$ \\
Role model & $0.018^{*}$ & 8.196 & $1.665-40.348$ \\
Strict time limits & 0.574 & 1.611 & $0.329-7.889$ \\
Workload & $0.204^{*}$ & 1.920 & $0.702-5.251$ \\
\hline
\end{tabular}

implementation of the handover. The related factors have been illustrated in Table 2 . The results of the analysis conducted by the researchers using Fisher's exact test had a p-value $=0.036(\alpha 0.05)$. It can thus be concluded that there is a relationship between the level of education and the implementation of handover in the inpatient ward of Ulin Hospital Banjarmasin.

The results of the analysis with Fisher's exact test obtained a p-value $=0.021(\alpha 0.05)$, which means that it can be concluded that there is a relationship between role models and the implementation of handover in the inpatient ward of Ulin Hospital Banjarmasin. The results of the analysis based on OR obtained a result of 8.196 (1.665-40.384). This is statistically significant and it is believed that $95 \%$ of the respondents have good role models and that by 8.196 times, they perform better handovers than the nurses who have bad role models. See on table 3 .

The results of the bivariate analysis carried out based on Table 4 above indicates that the variables level of education, motivation, role model and workload can be included in the multivariate modeling because the $\mathrm{p}$ value $<0.25$. Other variables such as attitude, intention and strict time limits have a p-value $>0.25$. The selection of the candidates for the variables cannot be entered into multivariate modeling. However, these variables were still analyzed using the multivariate method because in substance, the attitudes, intentions and time limits are variables that are very important when related to the implementation of handover.

Multivariate modeling was done by all of the candidate variables being tested together using multiple logistic regression tests. The variables that are considered valid were the variables with a p-value $<0.005$ and $p$ value $>0.005$ issued sequentially from this model. The results of the multiple logistic regression analysis obtained have been shown in Table 5 .

The results of the last modeling analysis after the education level were released showing the results of the motivation variables with a $\mathrm{p}$-value $=0.318$, workload variables with $p$-value $=0.301$ and role models with $p$ - value $=<0.05,0.031$. The conclusion of the multiple logistic regression tests are that role model is the factor that is very dominantly associated with the implementation of handover.

Based on the results, the most dominant factor from the analysis was the role model variable, which had the highest OR value of more than $10 \%$, meaning that nurses with good role models in the room have a chance that is 6.089 times greater at the implementation of good handover compared to nurses who have a role model that is not good. See on table 6 .

\section{DISCUSSION}

The results showed that the majority of respondents had vocational education (131 people; $75.3 \%$ ). This can be seen from the implementation of handover, which has a less good value, at $52.9 \%$. Based on this, the level of education greatly determines the ability of the nurses to carry out handover. Ihsan (2007) said that education is very important in influencing one's mind. An educated person, when encountering a problem, will try to think as clearly as possible when solving a problem. Educated people tend to be able to think calmly about a problem. This statement is in line with what Hidayat (2008) revealed, in that education is the first element that must be structured because through education, the development of the nursing profession will be directed and developed in accordance with the advancements in science and technology.

The level of education greatly determines the ability of the nurses to understand and apply the handover. Nurses who have a higher level of education will find it easier to understand the implementation of handover compared to nurses who have a lower level of education, in this case, vocational education. The ability of the nurse to understanding the handover concept can increase the nurses' knowledge in terms of handover implementation. This will have an effect on nurse 
Table 5. The results of the last multivariate modeling selection were the factors related to the handover implementation of nurses in the inpatient ward of Ulin Hospital Banjarmasin

\begin{tabular}{lllll}
\hline Variable & Sig & $\operatorname{Exp(B)}$ & $\begin{array}{l}\text { CI 95\% } \\
\text { Lower }\end{array}$ & Upper \\
\hline Motivation(1) & 0.318 & 1.835 & 0.558 & 6.042 \\
Role model & 0.031 & 6.089 & 1.178 & 31.469 \\
Workload & 0.301 & 1.750 & 0.606 & 5.050 \\
Constant & 0.000 & 0.006 & & \\
\hline
\end{tabular}

Table 6. Comparison of OR before and after the education level variable is excluded from the model of the relationship between the independent variables and the dependent variable on the handover implementation of nurses in the inpatient ward of Ulin Hospital Banjarmasin

\begin{tabular}{lcccc}
\hline Variable & $\begin{array}{l}\text { OR } \\
\text { complit }\end{array}$ & $\begin{array}{c}\text { Education } \\
\text { been issued }\end{array}$ & Calculation & Change OR \\
\hline Level of education (1) & 0.777 & - & - & - \\
Level of education (2) & 0.376 & - & - & - \\
Motivation (1) & 1.999 & 1.835 & $(1.835-1.999) / 1.999 \times 100 \%$ & $8.2 \%$ \\
Attitude & 0.967 & - & - & - \\
Intention & 2.584 & - & - & - \\
Role model & 3.397 & 6.089 & $(6.089-3.397) / 3.397 \times 100 \%$ & $79.2 \%$ \\
Strict time limits & 0.988 & - & - & - \\
Workload & 1.895 & 1.750 & $(1.750-1.895) / 1.895 \times 100 \%$ & $7.6 \%$ \\
\hline
\end{tabular}

compliance in terms of them implementing their duties and responsibilities when carrying out the handover.

The results of this study also showed that $43.7 \%$ of nurses had a negative attitude. This is based on the questionnaire focused on the handover procedure. Handover procedures, especially those related to the time of handover, require the nurses to arrive early to see the patient's condition. There are still nurses that have expressed disagreement with this. According to the researcher, this was not in line with the handover SPO in the hospital. The implementation of the handover, if carried out in accordance with the SPO, will reduce the errors involved in delivering the information both to the patient and to the nurse. Thus, the patient's safety can be protected.

Based on this study, most of the respondents had good role models, totaling 167 people (96.0\%) but there were still $4 \%$ nurses who had bad role models. Based on the results of the questionnaire, it was found that nurses who had role models that were not good did so because the implementing nurse saw that the head of the room did not carry out the handover in any situation. In this case, the researcher assumed that the implementation of a good handover is supported by a good role model, be it the head of the room, the supervisor or the team leader. On the other hand, when the implementation of handover is not good, the head room nurse factor has responsibility. As the head of the space, this nurse should be a good example of the implementation of handover.

The results of this study are in line with Bandura's Social Learning Theory (in Ashford, 2010) which suggests that individual behavior is formed through the imitation of environmental behavior. Individuals will observe the behavior in their environment as a model, meaning that support from peer nurses can also be used as role models in the implementation of handover. The nurse will imitate how his partner did the handover. If this is given reinforcement by the environment, then the behavior will become attached.

The attitude and behavior of the other officers is a role model for the other health workers. In line with Lankford et al's (2003) study stating that the compliance of janitors and health workers was significantly affected by the behavior of other health care workers, the compliance of the health workers is directly affected by the behavior of other health care workers. In this case, senior nurses can be the role models for other nurses. The more often that the junior nurses see the positive behavior of the senior nurses, the more positive the junior nurse's behavior is tied into what senior nurses do in terms of handovers. Conversely, if the behavior shown by the senior nurses is negative, then the junior nurses will behave like the senior nurses.

The results showed that the majority of respondents were there at the right time, totaling as many as 160 people (92.0\%). There were still 8\% who, in the handover, were not on time. The inaccuracy, based on the results of the questionnaire, found that the respondents could not finish the handover well within a short period of time. The results showed that the respondents who were unable to carry out the handover in a timely manner made up $8 \%$.

The research results showed that the majority of respondents carried out handover well, by as much as 157 (90.2\%) but there were still $19.8 \%$ of respondents whose operations were not good. This was due to the procedures implemented, based on the results of the questionnaire, namely signing the handover book at the end of the shift. The signing of the handover book is the most important part in the existing standard operating procedures (SPO), meaning that the nurses often carry out the handover not in accordance with the SPO of the hospital. Many factors have resulted in this, including the 
unavailability of an operative SPO in each room and non-compliant nurses.

Based on the results of the research that the implementing nurses who do the handover are mostly good, many factors can influence this, including high nurse motivation, positive nurse attitudes toward handover, having the intention to carry out the handover and having good role models in the implementation of handover such as from the headroom, supervisor and team leader. For most nurses carrying out handover, a lot of nurses have a low workload so the implementation of handover can be implemented properly.

The results of this study show that the education level of the respondents is more in terms of vocational education or Nursing DIII for as many as $75.3 \%$. Although the level of education is not the main factor that influences the implementation of handover for the nurses, the level of education and the knowledge of a person can influence a person's behavior. Ihsan (2007) argues that education is a very important thing when it comes to influencing one's mind. An educated person, when encountering a problem, will try to think as clearly as possible when solving the problem. Educated people tend to be able to think calmly about a problem.

The results of Fisher's analysis of the exact tests in this study indicated that there is a relationship between the level of education and the implementation of nurse handover with a p-value 0.025 . The level of education greatly determines the ability of the nurses to carry out the handovers. This is in line with what Hidayat (2008) revealed, in that education is the first element that must be structured because through education, the development of the nursing profession will be directed and developed in accordance with the advancement of science and technology so then the nursing staff can be qualified.

The results of this study indicate that the majority of respondents (56.3\%) had a positive attitude towards the implementation of handover. The Chisquare statistical test results obtained p-value 0.767 , means that $\mathrm{H}_{\mathrm{o}}$ is accepted. It can thus be concluded that there is no relationship between attitude and nurse handover implementation.

Although in the research conducted by the researchers there was no relationship between attitude and the implementation of nurse handover, the attitude formed in a person can influence someone in carrying out their daily tasks. With a positive attitude, it is expected that someone has a high standard of performance and motivation. Attitude clearly indicates the connotation of the suitability of the reaction to a particular stimulus which in everyday life is an emotional reaction to a social stimulus.

Based on the results of the cross-tabulation analysis between attitude and handover, it was found that the nurses had a negative attitude towards handover. For the nurses who had a negative attitude, there were still nurses among them who performed the handover well (89.5\%) while the rest did it less so
(10.5\%). Handover procedures, especially those related to the timing of the handover, require the nurse to arrive early and to see the patient's condition firsthand. However, there are still nurses who state that they do not agree with this. According to the researcher, this was not in line with the handover protocol in the hospital. It should have been carried out according to the existing protocol to reduce the errors involved in delivering information to both the patients and nurses and to ensure patient safety.

The attitude of the nurses in the implementation of handover can be influential. The attitude that has been formed in and by the nurse can affect the nurses when they are carrying out their daily duties in the hospital, one of which in this case is the implementation of handover. Attitude significantly shows the connotation of the suitability of reactions to certain stimuli in daily life and it is an emotional reaction to social stimulus.

The attitude and behavior of other officers is a role model for other health workers as a role model. In line with Lankford et al's (2003) study that stated that the compliance of janitors and health workers was significantly affected by the behavior of other health care workers, the compliance of health workers is directly affected by the behavior of other health care workers. In this case, senior nurses can be role models for other nurses. The more often that junior nurses see the positive behavior of senior nurses, the more positive the junior nurse's behavior will be and vice versa.

Based on the results of the study indicating that there is a relationship between role models and the implementation of handover, this means that the better the role models are that are possessed by junior nurses in the handover, the better the handovers are performed. Role models have a very important role in an organization, especially for hospital nurses. The more good nurse role models there are, the more likely it is that other nurses will follow them. Role models in this study are the factor most associated with the implementation of handover from other factors like the level of education, motivation, attitudes, intentions, strict time limits and workload.

Based on the results of the multivariate analysis of the seven independent variables (level of education, motivation, attitudes, intentions, role models, strict time constraints and workload), only one was the most dominant one related to nurse handover, namely role models with an OR of 6.089. This reveals that role models are the most dominant variable in relation to nurse handover.

The results of testing all of the variables that are related or not by entering all of the variables in the first stage turned out to be a time limit that has a larger value, so that it was excluded from the analysis. In the second stage, the attitude value with the largest value was excluded from the analysis, and then after the time limit variable and the attitude variable were issued, there was still no change. It can be seen from the results of the OR comparison in Table 5.12 that 
there is no change in OR that is $>10 \%$, so the strict time limit variable was removed from the model. Furthermore, the biggest variable $p$-value is the attitude variable with a p-value 0.955 . Thus, the next modeling attitude variable was removed from the model.

Through the next stage after the time limit with the attitude being released, it turns out that the level of education is greater in value so the model was released but from the results of the OR comparison in Table 5.16, there were changes in OR $>10 \%$ including in the intention variables and role models variable. Thus, the education level variable was included again in the model. The analysis was carried out again by entering the education level variable but when we issued an intention variable, the results of the OR comparison in Table 5.19 showed no change in OR which $>10 \%$ of them. Thus, the intention variable is excluded from the modeling and as can be seen from the $p$ value of the largest level of education, the education level was released from the model. The results of the last modeling analysis after the education level were released show that the results of the motivation variables are p-value 0.318, the workload variables are p-value 0.301 and only role models are $p$-value $<0.05,0.031$. The conclusion of the multiple logistic regression tests are that role models are the factor that is very dominant when related to the implementation of handover.

Based on the results of the analysis, it can be seen that the level of education and intention can influence the role model, as evidenced that when analyzed, there was a change in the percentage of the variable for role models after the education level was released as well as the intention variable. As a nurse who is a role model for other nurses, they must be supported with a higher level of education and accompanied by good intentions. The hospital management must be able to determine and choose those who not only see the seniority of the person who is the team leader or head of the room as a role model for other nurses and they must also look at the education of the nurses, but the management must also consider the level of education of a nurse who wants to be the team leader or head of the room and see the education level of the nurse in question. This is because with education being in terms of academic and professional stages, there are a few people who, when they are educated in college, have already exposed to science. However, this may not be obtained more deeply when they are studying in the vocational stage in the case of some handovers. Likewise, with the nursing nurse, the education level of the implementing nurse can affect the nurse who is a role model, which in this case is the head of the room, supervisor or team leader. The higher the level of education of the executive nurses, the more they are able to respect their superiors, imitate the best and leave the bad ones. In contrast, a low level of nurse education from their superiors will make it difficult for them to imitate and obey their superiors.
Based on the research conducted by Vrischa (2015), it was found that there was a significant relationship between the factors that influence handover - one of which was education. In line with the research mentioned above, the results of the research conducted by the researchers in this study also showed that the level of education in terms of the relationship of the implementation of handover in the treatment room was related, The more specialist the level of education of a person, the more that someone's knowledge increases. The increase in knowledge will lead to an awareness of a person which will cause people to behave, whereas for the higher levels of knowledge of the nurses, it will result in a more positive and higher motivation in those carrying out the handover. With a high level of education in someone knows theoretically about handover, they will know more about their professional work. Education has also been regulated in terms of ongoing professional development for Indonesian nurses (2013), in order to maintain and enhance their professionalism as a nurse according to the established competency standards. This has been done through education and training. For the development of continuous professionalism for nurses in accordance with Law No. 36 of 2009 concerning Health Article 27, it states that health workers - in carrying out their duties - are obliged to develop and improve their knowledge and skills. With the ongoing professional development and mandate of Law No. 36 of 2009, nurses are required to always develop themselves in this matter through continuing their education. If the knowledge of handover has not been obtained during the vocational education they have undergone, then the nurses are required to undertake professional education.

Hayes (2016) stated that the continuation of education and professional development / Continuing Professional Development (CPD) will improve the professionalism of a nurse in the cognitive, psychomotor and affective domains. The competencies possessed by the nurses will be increased or decreased. Various methods are needed, including formal education, seminars, training and workshops, so then they will provide benefits relate to staff development in terms of knowledge, skills, and attitude.

Social Learning Theory Bandura (1971), which is a Bandura modeling that is a combination of habit factors with cognitive factors, revealed that in learning, there are six ways that it can be done, namely 1) trial-and-error experience; learning through trial and error, 2) the perception of the object,; learning is done by giving an opinion or estimate of an object, 3) observations of another's response to the object; learning can also be done through studying the opinions or responses of others, 4) modeling; learning can also be done by creating or determining a model or example, 5) exhortation; learning can also be based on the various advice obtained, both directly and indirectly, and 6) instructions about the object; learning can be through 
various commands that are deliberately given based on the object or thing that is to be learned. The learning done by a nurse in handover is, according to the results of the research and Bandura theory, through models. Modeling in this case is learning through a model or example, which is where someone often sees someone taking an action in the case of a nurses' handover. Then the other nurse will pass along these actions as well.

This research had various limitations, even though efforts have been made to overcome them. These limitations included that this research was carried out in all inpatient rooms so the filling in the questionnaire by the executive nurses meant that the researchers were unable to fully oversee the filling in of the questionnaires. The researchers also could not fully control and see directly when the respondents answered the questionnaire.

\section{CONCLUSION}

Motivation, attitude, intention, strict time limits and workload were not related to the implementation of nurse handover. The level of education and role model were related to the implementation of handover. Having a role model was the most dominant factor associated with nurse handover implementation. The suggestions of this study are that the nurses who serve as the head of the room, supervisor and team leader should provide an example or role model to the nurses in relation to the implementation of handover. For other researchers, they should develop research with a qualitative design that can explore the various phenomena regarding the perception, experience and contribution of nurses related to the implementation of handover as performed by the nurses.

\section{REFERENCES}

Bandura. (1971). bandura_sociallearningtheory.pdf. New York: General Learning Press.
Dewi, M. (2012). Pengaruh pelatihan timbang terima pasien terhadap penerapan keselamatan pasien oleh perawat pelaksana di RSUD Raden Mattaher Jambi. Jurnal Health and Sport, 5(03).

Hidayat, A. A. (2008). Pengantar Konsep Dasar Keperawatan.Cetakan Ketiga. Jakarta: Salemmba Medika.

Ihsan, F. (2007). Dasar-Dasar Kependidikan. Jakarta: Rineka Cipta.

Lankford, M. G., Zembower, T. R., Trick, W. E., Hacek, D. M., Noskin, G. A., \& Peterson, L. R. (2003). Influence of role models and hospital design on the hand hygiene of health-care workers. Emerging Infectious Diseases, 9(2), 217.

Nursalam. (2014). Manajemen Keperawatan Aplikasi Keperawatan Profesional Edisi 4, 342.

Nursalam. (2015). Manajemen Keperawatan: Aplikasi dalam Praktik Keperawatan Profesional (Edisi 5). Jakarta: Salemba Medika.

Organization, W. H., \& others. (2007). Communication during patient hand-overs. Patient Safety Solutions, 1(3), 1-4.

Permenkes RI. (2011). No. 1691 Tentang Keselamatan Pasien Rumah Sakit.

Safitri, R. (2012). Pengaruh Teknik Komunikasi SBAR Terhadap Motivasi dan Kepuasan Perawat Dalam Melakukan Operan di Ruang Rawat Inap RSUP Dr. M. Djamil Padang, 1-12.

Triwibowo, C., \& Harahap, Z. (2016). Studi Kualitatif: Peran Handover dalam Meningkatkan Keselamatan Pasien di Rumah Sakit. Jurnal Pena Medika, 6(2), 72-79.

Triwibowo, C., Harahap, Z., \& others. (2016). Studi Kualitatif: Peran Handover dalam Meningkatkan Keselamatan Pasien di Rumah Sakit. Pena Medika Jurnal Kesehatan, 6(2).

Vrischa T, M. (2015). Analisis Faktor-faktor yang mempengaruhi timbang terima di rruang rawat inap Rumah Sakit Grha Kedoya Jakarta Barat. Biomass Chem Eng, 49(23-6), 22-23. 